\title{
EFEK PRIMING TERHADAP VIGOR BENIH KEDELAI (Glycine max (L.) Merril.) YANG DIKECAMBAHKAN PADA MEDIA DENGAN CEKAMAN ALUMINIUM
}

\section{EFFECT OF PRIMING ON VIGOR OF SOYBEAN (Glycine max (L.) Merril.) SEEDS GERMINATED IN ALUMINIUM STRESS CONDITION}

\author{
Agustiansyah*, Paul B. Timotiwu, Nabila Lutfiah \\ Jurusan Agronomi dan Hortikultura, Fakultas Pertanian, Universitas Lampung \\ Jl. Prof. Soemantri Brodjonegro No.1, Bandar Lampung 35145 \\ *Korespondensi : agustiansyah.1972@fp.unila.ac.id
}

Diterima : 21 Juli 2021 / Disetujui : 17 November 2021

\begin{abstract}
ABSTRAK
Kandungan aluminium yang tinggi pada tanah Ultisol merupakan salah satu masalah utama dalam budidaya tanaman kedelai mulai dari fase perkecambahan hingga pertumbuhan tanaman. Perlakuan priming pada benih diyakini mampu memperbaiki perkecambahan pada lingkungan yang kurang menguntungkan. Penelitian dilakukan untuk mengetahui pengaruh priming pada perkecambahan benih kedelai yang dikecambahkan dalam media masam dan mengandung aluminium. Penelitian disusun dalam Rancangan Acak Lengkap (RAL) pola faktorial. Faktor pertama adalah jenis priming : tanpa priming, $\mathrm{H}_{2} \mathrm{O}$ (air), $\mathrm{KNO}_{3} 1 \%, \mathrm{KNO}_{3} 2 \%$, $\mathrm{GA}_{3} 50$ ppm, GA 100 ppm, dan PEG 6000 7,5\%. Faktor kedua adalah varietas kedelai yaitu: Anjasmoro, Burangrang, dan Grobogan. Data dianalisis sidik ragamnya dan dilanjutkan dengan uji Beda Nyata Jujur (BNJ) 5\% menggunakan program statistika R Studio. Hasil penelitian menunjukkan priming PEG 7,5\% dan varietas Burangrang secara mandiri merupakan perlakuan terbaik untuk meningkatkan vigor benih kedelai berdasarkan variabel waktu muncul kecambah, kecepatan perkecambahan, dan panjang hipokotil. Implikasi penelitian ini adalah PEG 7,5\% dapat digunakan untuk perbaikan perkecambahan pada tanah masam dengan kandungan aluminium yang relatif tinggi.
\end{abstract}

Kata kunci: Aluminium, Benih, Cekaman, Kedelai, Priming

\begin{abstract}
High aluminium content in Ultisol is the main problem in soybean cultivation from germination to planting growth phases. Priming treatment is believed to improve seed germination in a poor-growing environment. This study aimed to determine the effect of priming of soybean seeds germinated under acid medium and aluminium stress. The experimental design used was Completely Randomized Design (CRD) with factorial pattern. The first factor was priming type : no priming, $\mathrm{H}_{2} \mathrm{O}$ (water), $1 \% \mathrm{KNO}_{3}, 2 \% \mathrm{KNO}_{3}, 50 \mathrm{ppm} \mathrm{GA}_{3}$, $100 \mathrm{ppm} \mathrm{GA}$, and 7.5\% PEG 6000. The second factor was soybean variety : Anjasmoro, Burangrang, and Grobogan. The data obtained were analyzed using the R Studio statistic program with a 5\% HSD test. The study resulted that each PEG 7.5\% priming and Burangrang
\end{abstract}

Cite this as: Agustiansyah., Timotiwu, B, P., \& Lutfiah, N. (2021). Pengaruh priming terhadap vigor benih kedelai (Glycine max (L.) Merril.) yang dikecambahkan pada media dengan cekaman alumunium. Jurnal Agro, 8(2), 178-187. https://doi.org/10.15575/13458 
variety independently was the best in increasing soybean seed vigor based on sprout time emergence, germination speed and hypocotyl length. This research implicates that PEG $7.5 \%$ can be used to improve seed germination on acid soils with high aluminium content.

Keywords: Aluminium, Priming, Seed, Soybean, Stress

\section{PENDAHULUAN}

Pertambahan jumlah penduduk dan peningkatan kebutuhan industri olahan pangan berbahan baku kedelai membuat kebutuhan kedelai di Indoneisa terus meningkat. Menurut Badan Pusat Statistik (2020), konsumsi kedelai di Indonesia dari tahun 2016-2020 berturut-turut yaitu $2.262 .662,953 \mathrm{~kg}, \quad 2.672 .452,828 \mathrm{~kg}$, $2.586 .791,698 \mathrm{~kg}, \quad 2.670 .086,4 \mathrm{~kg}$, dan $2.475 .286,7 \mathrm{~kg}$. Kebutuhan yang meningkat tersebut belum diimbangi dengan peningkatan produksi dalam budidaya kedelai. Menurut BPS (2021), produksi kedelai di Propinsi Lampung tahuan 2015 sebesar 19,628 t sedangkan produksi ratarata per wilayah di Indonesia sebesar 28,329 t untuk tahun yang sama, sehingga Propinsi Lampung terus berupaya memperluas penanaman dan melakukan perbaikan budidaya kedelai.

Salah satu penyebab rendahnya produksi kedelai terutama di Provinsi Lampung adalah cekaman media tanam mulai dari fase perkecambahan sampai pertumbuhan tanaman, karena kedelai di Lampung banyak ditanam di lahan kering yang merupakan tanah Ultisol. Tanah Ultisol memiliki karakter pH berkisar 4,6 - 6,0 (Sudrajat, 2010), tinggi kandungan aluminium (Al) (Kuswantoro et al., 2014). Kandungan aluminium tinggi menyebabkan terhambatnya perkecambahan benih (Kochian et al., 2004) dan terhambatnya pertumbuhan tanaman (Adie \& Krisnawati, 2016; Uguru et al., 2012) dengan menghambat pemanjangan akar karena terhambatnya pembelahan sel yang disebabkan pengikatan DNA oleh Al (Marschner, 2003).

Upaya yang dapat dilakukan untuk meningkatkan vigor benih dan keberhasilan perkecambahan pada tanah asam dengan kandungan Al tinggi adalah dengan melakukan priming pada benih yang akan ditanam. Menurut Nawaz et al. (2013) priming adalah menyiapkan proses metabolisme benih sehingga lebih siap berkecambah tanpa munculnya plumula atau radikula. Benih akan menyerap air yang cukup untuk mempercepat proses perkecambahan pada tanaman. Teknik ini telah terbukti dapat mengatasi kegagalan perkecambahan karena stress lingkungan masam (Langeroodi \& Noora, 2017), cekaman kekeringan (Latifa \& Diah Rachmawati, 2020), cekaman penyakit (Leite et al., 2003), dan cekaman salinitas (Janmohammadi et al., 2008).

Beberapa jenis teknik priming yang dikenal adalah hydro priming, halo priming, osmopriming, dan hormonal priming. Hydro priming adalah perendaman benih pada air sebelum dikecambahkan (Pill \& Necker, 2001). Halo priming adalah perendaman benih dalam larutan garam anorganik seperti $\mathrm{NaCl}, \mathrm{KNO}_{3}, \mathrm{CaCl}_{2}, \mathrm{CaSO}_{4}$, dan garam mineral lainnya (Karimi \& Varyani, 2016). Osmopriming merupakan perendaman benih dalam larutan gula, Polyethylene Glycol (Lutts et al., 2016). Hormonal priming adalah perlakuan pratanam benih 
dengan hormon tanaman (Nawaz et al., 2013).

Penelitian ini bertujuan mengetahui pengaruh perlakuan priming pada vigor benih kedelai yang dikecambahkan pada media dengan cekaman aluminium sebagai simulasi cekaman pada tanah ultisol di lapangan.

\section{BAHAN DAN METODE}

Penelitian ini dilaksanakan di Laboratorium Benih dan Pemuliaan Tanaman, Fakultas Pertanian, Universitas Lampung. Penelitian dilakukan dari bulan November 2020 sampai dengan Maret 2021. Percobaan dilakukan dalam Rancangan Acak Lengkap (RAL) yang diulang tiga kali dan perlakuan disusun secara faktorial. Faktor pertama adalah tanpa priming, priming dalam $\mathrm{KNO}_{3} 1 \%$ dan $2 \%$ (Miladinov et al., 2018); air, Giberelin $\left(\mathrm{GA}_{3}\right)$ 50 ppm dan 100 ppm (Langeroodi \& Noora 2017) dan Polyethylene Glycol (PEG) 6000 $7,5 \%$. Faktor kedua adalah 3 varietas kedelai yang terdiri dari Anjasmoro, Burangrang, dan Grobogan.

Priming diterapkan dengan cara merendam benih kedelai dari ketiga varietas tersebut (Anjasmoro, Burangrang dan Grobogan), sesuai dengan perlakuan yaitu priming dengan air selama 12 jam, $\mathrm{KNO}_{3} 1 \%$ dan $2 \%$ selama $6 \mathrm{jam}, \mathrm{GA}_{3} 50 \mathrm{ppm}$ dan 100 ppm selama 14 jam, dan PEG 7,5\% selama 24 jam). Setelah benih direndam, kemudian benih dikering-anginkan. Benih dikecambahkan dengan metode Uji Kertas Digulung dengan Plastik (UKdP). Sebanyak
25 butir benih dikecambahkan dalam setiap gulungan kertas untuk setiap perlakuan per ulangan. Kertas yang digunakan untuk mengecambahkan benih adalah CD (kertas koran putih licin) yang telah direndam dalam larutan $\mathrm{Al} \quad\left(\mathrm{AlCl}_{3} .6 \mathrm{H}_{2} \mathrm{O}\right)$ dengan konsentrasi 0,05 mM dan memiliki $\mathrm{pH}$ 4,34,5 (Timotiwu \& Agustiansyah, 2006). Gulungan kertas yang berisi benih kedelai tersebut selanjutnya diletakkan dalam germinator tipe IPB 73-2B.

Pengamatan meliputi daya berkecambah, waktu munculnya kecambah yang ditandai munculnya radikula, kecepatan berkecambah, berat kering kecambah, panjang hipokotil, dan panjang akar radikula. Data yang diperoleh dianalisis sidik ragamnya dan dilanjutkan dengan uji Beda Nyata Jujur (BNJ) $5 \%$ menggunakan program statistika R Studio.

\section{HASIL DAN PEMBAHASAN}

Hasil percobaan menunjukkan bahwa perlakuan priming memberikan pengaruh nyata pada vigor benih yang dikecambahkan pada media mengandung aluminium. Hal ini dapat dilihat dari beberapa variabel seperti waktu munculnya kecambah, kecepatan berkecambah, bobot kering kecambah, panjang hipokotil, dan panjang akar radikula. Ketiga varietas memberikan respons yang berbeda terhadap perlakuan priming dan terdapat interaksi antara perlakuan priming dan varietas pada variabel berat kering kecambah dan dan panjang akar radikula (Tabel 1). 
Tabel 1. Hasil analisis ragam pengaruh priming terhadap vigor benih kedelai yang dikecambahkan pada media dengan cekaman aluminium

\begin{tabular}{lccc}
\hline Variabel & $\mathrm{P}$ & $\mathrm{V}$ & $\mathrm{V} \times \mathrm{P}$ \\
\hline Waktu munculnya kecambah (hari) & $* *$ & $* *$ & tn \\
Kecepatan berkecambah (hari) & $* *$ & $* *$ & tn \\
Daya berkecambah (\%) & tn & tn & tn \\
Berat kering kecambah (gram) & $*$ & tn & $*$ \\
Panjang hipokotil $(\mathrm{cm})$ & $* *$ & $* *$ & tn \\
Panjang akar radikula $(\mathrm{cm})$ & $* *$ & $* *$ & $* *$ \\
\hline
\end{tabular}

Ket: $\mathrm{tn}=$ tidak nyata, ${ }^{*}=$ nyata pada $\alpha 5 \%,{ }^{* *}=$ sangat nyata pada $\alpha 1 \%$.

Berdasarkan hasil penelitian, perlakuan priming pada benih kedelai dapat meningkatkan vigor benih kedelai yang dikecambahkan pada media mengandung aluminium. Vigor yang meningkat tersebut ditunjukkan pada variabel waktu munculnya kecambah tercepat pada hari ke-1,19 dengan perlakuan priming PEG $7,5 \%$ dibandingkan kontrol yang muncul pada hari ke-2,07 dan variabel kecepatan berkecambah tertinggi pada priming dengan PEG $7,5 \%$ yaitu $27,34 \%$ hari $^{-1}$ dibandingkan kontrol 20,15\% hari $^{-1}$ walaupun tidak berbeda dengan perlakuan priming lainnya. Selain PEG, perlakuan priming dengan air, $\mathrm{GA}_{3} 50$ ppm, $\mathrm{GA}_{3} 100$ ppm, $\mathrm{KNO}_{3} 1 \%$, dan $\mathrm{KNO}_{3} 2 \%$ juga dapat meningkatkan vigor benih pada kondisi media stress Al (Tabel 2).

Keberhasilan priming dalam meningkatkan vigor benih kedelai sejalan dengan penelitian Langeroodi \& Noora (2017); Čanak et al. (2016) pada jagung, Sulaiman et al. (2016) pada padi, dan AlBaldawi \& Hamza (2017) pada sorgum. Perlakuan priming pada benih dapat meningkatkan kemampuan tanaman menghadapi stress abiotik seperti tanah asam, tanah dengan salinitas tinggi dan kekeringan (Widyastuti et al., 2017; Miladinov et al., 2014; Singh \& Laxmi,
2015). Polyethylene Glycol (PEG) mampu meningkatkan vigor benih kedelai yang dikecambahkan pada kondisi cekaman aluminium. Hal ini disebabkan potensial air di sekitar benih menjadi lebih rendah, sehingga laju serapan air pada awal imbibisi dapat diatur oleh PEG. Menurut Maslukah et al. (2019), PEG adalah senyawa yang dapat menurunkan potensial osmotik larutan yang mampu mengikat molekul air dengan ikatan hidrogen. Sedangkan Menurut Amoozadeh et al. (2013) penggunaan PEG yang dikecambahkan pada cekaman aluminium memiliki respons yang baik karena PEG dapat mengikat aluminium, sehingga air tetap tersedia.

Perlakuan perendaman $\mathrm{GA}_{3}$ juga meningkatkan vigor benih kedelai saat dikecambahkan dalam kondisi cekaman aluminium sejalan dengan penelitian Supardy et al. (2016) pada tanaman kakao dan sorgum (Al-Baldawi \& Hamza, 2017). Pada perkecambahan benih, Giberelin mengaktifkan reaksi enzimatik di dalam aleuron (Bey et al., 2005). Mendorong pelepasan enzim amilase untuk menghidrolis cadangan makanan dan energi yang dihasilkan disalurkan untuk perkecambahan benih (Dewi \& Sutrisno, 2013). 
Tabel 2. Pengaruh priming terhadap vigor kedelai yang dikecambahkan pada media dengan cekaman aluminium

\begin{tabular}{llccc}
\hline Priming & $\begin{array}{l}\text { WMK } \\
\text { (hari) }\end{array}$ & $\begin{array}{c}\text { KCT } \\
\left(\% \text { hari }^{-1}\right)\end{array}$ & $\begin{array}{c}\text { DB } \\
(\%)\end{array}$ & $\begin{array}{c}\mathrm{pH} \\
(\mathrm{cm})\end{array}$ \\
\hline Kontrol & $2,07 \mathrm{a}$ & $20,15 \mathrm{~b}$ & $84,00 \mathrm{a}$ & $9,45 \mathrm{c}$ \\
Air & $1,29 \mathrm{bc}$ & $25,95 \mathrm{a}$ & $83,11 \mathrm{a}$ & $14,86 \mathrm{a}$ \\
$\mathrm{KNO}_{3} 1 \%$ & $1,46 \mathrm{bc}$ & $24,60 \mathrm{a}$ & $84,89 \mathrm{a}$ & $12,02 \mathrm{~b}$ \\
$\mathrm{KNO}_{3} 2 \%$ & $1,52 \mathrm{~b}$ & $25,99 \mathrm{a}$ & $83,56 \mathrm{a}$ & $11,74 \mathrm{~b}$ \\
$\mathrm{GA}_{3} 50 \mathrm{ppm}$ & $1,37 \mathrm{bc}$ & $24,85 \mathrm{a}$ & $81,33 \mathrm{a}$ & $14,70 \mathrm{a}$ \\
$\mathrm{GA}_{3} 100 \mathrm{ppm}$ & $1,40 \mathrm{bc}$ & $23,80 \mathrm{ab}$ & $82,67 \mathrm{a}$ & $13,96 \mathrm{a}$ \\
PEG 6000 7,5\% & $1,19 \mathrm{c}$ & $27,34 \mathrm{a}$ & $82,67 \mathrm{a}$ & $8,54 \mathrm{c}$ \\
\hline
\end{tabular}

Ket: Angka-angka pada satu kolom yang sama yang diikuti oleh huruf yang sama, tidak berbeda pada Uji BNJ dengan $\alpha$ 5\%. WMK = Waktu Munculnya Kecambah; $\mathrm{KCT}=$ Kecepatan Berkecambah; $\mathrm{DB}=$ Daya Berkecambah; PH = Panjang Hipokotil

Ketiga varietas memiliki respons yang berbeda. Benih varietas Burangrang menunjukkan respons yang lebih baik pada variabel kecepatan pertumbuhan dan panjang hipokotil. Sementara pada variabel waktu munculnya kecambah dan daya berkecambah memiliki respons yang tidak berbeda dengan varietas Anjasmoro dan varietas Grobogan. Hal ini menandakan bahwa benih varietas Burangrang menunjukkan vigor yang lebih baik pada kondisi stress aluminium (Tabel 3).
Beberapa peneliti melaporkan perlakuan priming dipengaruhi oleh faktor genetik antara lain pada tanaman kedelai (Lewandowska et al., 2020; Sucahyono et al., 2014); timun (Anwar et al., 2020); cabai (Ulya et al., 2020), padi (Sulaiman et al., 2016). Ketiga varietas yang digunakan (Burangrang, Anjasmoro, dan Grobogan), memiliki perbedaan dalam bobot 100 butir. Menurut Balitkabi (2016), bobot 100 butir masing-masing varietas tersebut adalah 17 g, $14,8-15,3 \mathrm{~g}$, dan $\pm 18 \mathrm{~g}$ berturut-turut.

Tabel 3. Pengaruh varietas terhadap vigor benih tiga varietas kedelai yang dikecambahkan pada media dengan cekaman aluminium

\begin{tabular}{llccc}
\hline Varietas & $\begin{array}{l}\text { WMK } \\
\text { (hari) }\end{array}$ & $\begin{array}{c}\text { KCT } \\
\left(\% \text { hari }^{-1}\right)\end{array}$ & $\begin{array}{c}\text { DB } \\
(\%)\end{array}$ & $\begin{array}{c}\mathrm{pH} \\
(\mathrm{cm})\end{array}$ \\
\hline Anjasmoro & $1,49 \mathrm{ab}$ & $23,71 \mathrm{~b}$ & $84,76 \mathrm{a}$ & $11,59 \mathrm{~b}$ \\
Burangrang & $1,38 \mathrm{~b}$ & $26,07 \mathrm{a}$ & $83,81 \mathrm{a}$ & $13,07 \mathrm{a}$ \\
Grobogan & $1,54 \mathrm{a}$ & $24,24 \mathrm{ab}$ & $80,95 \mathrm{a}$ & $11,88 \mathrm{~b}$ \\
\hline
\end{tabular}

Ket: $\mathrm{WMK}=$ Waktu Munculnya Kecambah; KCT = Kecepatan Berkecambah; DB = Daya Berkecambah ; $\mathrm{PH}=$ Panjang Hipokotil

Pada beberapa variabel terdapat interaksi antara perlakuan priming dan varietas. Pada variabel berat kering kecambah, untuk semua perlakuan priming pada varietas Anjasmoro dan Burangrang tidak menunjukkan perbedaan respons, kecuali pada varietas Grobogan yang memiliki respons beragam dan tertinggi untuk berat kering kecambah pada kontrol yaitu 2,55 g. Interaksi antar varietas pada perlakuan kontrol (tanpa priming) untuk varietas Grobogan dan Burangrang tidak berbeda sedangkan Grobogan berbeda dengan Anjasmoro. Priming air pada 
varietas Burangrang dan Anjasmoro tidak berbeda, sedangkan pada Burangrang dan Grobogan berbeda. Priming $\mathrm{KNO}_{3} 1 \%$ pada varitas Grobogan, Anjasmoro, dan Burangrang tidak menunjukkan adanya perbedaan. Priming $\mathrm{KNO}_{3} \quad 2 \%$ varietas Grobogan, Anjasmoro, dan Burangrang tidak ada perbedaan. Priming Giberelin 50 ppm juga tidak menunjukkan adanya perbedaan di antara varietas Anjasmoro, Burangrang dan Grobogan. Priming Giberelin 100 ppm tidak berbeda antar ketiga varietas yang diuji. Priming PEG $7,5 \% \%$ pada varietas Grobogan dan Burangrang tidak berbeda sedangkan varietas Grobogan dan Anjasmoro berbeda (Tabel 4).

Menurut Anosheh et al. (2011) $\mathrm{KNO}_{3}$ mengandung unsur kalium dan nitrogen yang dapat memacu munculnya titik tumbuh dan meningkatkan penyerapan air oleh protoplasma. Adapun nitrogen dalam sel dapat mensintesis asam amino dan protein dalam endosperm.

Menurut Balitkabi (2016), benih kedelai varietas Grobogan memiliki bobot 100 biji $18 \mathrm{~g}$ dan lebih berat dibandingkan varietas Anjasmoro dan Grobogan. Oleh karena itu berat kering kecambah juga lebih tinggi. Sedangkan benih kedelai varietas Anjasmoro dan Burangrang cadangan makanannya sudah habis, sehingga berat keringnya rendah. Cadangan makanan yang tinggi membuat berat kering tetap tinggi, karena masih terdapat cadangan makanan yang berasal dari kotiledon.

Tabel 4. Interaksi priming $\mathrm{x}$ varietas pada berat kering kecambah pada media dengan cekaman aluminium

\begin{tabular}{lccc}
\hline Priming & Anjasmoro & Burangrang & Grobogan \\
\hline Kontrol & $1,84 \mathrm{~b}$ & $2,22 \mathrm{ab}$ & $2,55 \mathrm{a}$ \\
& $\mathrm{A}$ & $\mathrm{A}$ & $\mathrm{A}$ \\
$\mathrm{Air}$ & $1,94 \mathrm{ab}$ & $2,06 \mathrm{a}$ & $1,52 \mathrm{~b}$ \\
$\mathrm{KNO}_{3} 1 \%$ & $\mathrm{~A}$ & $\mathrm{~A}$ & $\mathrm{~B}$ \\
& $1,95 \mathrm{a}$ & $1,85 \mathrm{a}$ & $1,99 \mathrm{a}$ \\
$\mathrm{KNO}_{3} 2 \%$ & $\mathrm{~A}$ & $\mathrm{~A}$ & $\mathrm{AB}$ \\
& $1,93 \mathrm{a}$ & $1,78 \mathrm{a}$ & $1,97 \mathrm{a}$ \\
$\mathrm{GA}_{3} 50 \mathrm{ppm}$ & $\mathrm{A}$ & $\mathrm{A}$ & $\mathrm{AB}$ \\
& $1,95 \mathrm{a}$ & $1,83 \mathrm{a}$ & $1,65 \mathrm{a}$ \\
$\mathrm{GA}_{3} 100 \mathrm{ppm}$ & $\mathrm{A}$ & $\mathrm{A}$ & $\mathrm{B}$ \\
& $1,80 \mathrm{a}$ & $1,71 \mathrm{a}$ & $1,65 \mathrm{a}$ \\
$\mathrm{PEG} 60007,5 \%$ & $\mathrm{~A}$ & $\mathrm{~A}$ & $\mathrm{~B}$ \\
& $1,48 \mathrm{~b}$ & $1,83 \mathrm{ab}$ & $2,08 \mathrm{a}$ \\
& $\mathrm{A}$ & $\mathrm{A}$ & $\mathrm{AB}$ \\
\hline
\end{tabular}

Ket : Angka-angka yang diikuti huruf kecil yang sama pada baris yang sama dan angka-angka yang diikuti huruf besar pada kolom yang sama tidak berbeda pada uji BNJ $5 \%$.

Interaksi juga didapat pada variabel panjang radikula. Perlakuan priming pada varietas Anjasmoro menunjukkan bahwa perlakuan priming air, diikuti dengan Giberelin 50 ppm, $\mathrm{KNO}_{3} 1 \%, \mathrm{KNO}_{3} 2 \%$, dan Giberelin 100 ppm berbeda dengan kontrol dan PEG 7,5\%. Pada varietas Burangrang priming PEG 7,5\% dan Giberelin 50 ppm tidak berbeda, diikuti dengan priming air, $\mathrm{KNO}_{3} 1 \%, \mathrm{KNO}_{3} 2 \%$, dan Giberelin 100 ppm tidak berbeda dan kontrol berbeda dengan PEG 7,5\% dan Giberelin 50 ppm. Varietas Grobogan priming $\mathrm{KNO}_{3} 2 \%$, diikuti dengan $\mathrm{KNO}_{3} 1 \%$ dan air tidak berbeda, diikuti 
dengan kontrol dan PEG 7,5\% sedangkan Giberelin 50 ppm dan Giberelin 100 ppm berbeda dengan $\mathrm{KNO}_{3} 2 \%$. Perlakuan tanpa priming antara varietas Burangrang dan Grobogan tidak berbeda sedangkan varietas Anjasmoro berbeda dengan varietas Burangrang. Priming air tidak menunjukkan adanya perbedaan antarvarietas Anjasmoro, Burangrang dan Grobogan. Priming $\mathrm{KNO}_{3} 1 \%$ pada varitas Burangrang, Anjasmoro dan Grobogan tidak menunjukkan adanya perbedaan. Priming $\mathrm{KNO}_{3} 2 \%$ varietas Grobogan, Anjasmoro dan Burangrang tidak ada perbedaan. Priming $\mathrm{GA}_{3} 50$ ppm menunjukkan pada varietas Burangrang dan Anjasmoro berbeda dengan varietas Grobogan. Priming $\mathrm{GA}_{3} 100$ ppm pada varietas Burangrang dan Anjasmoro berbeda dengan Grobogan. Priming PEG 7,5\% pada varietas Burangrang berbeda dengan varietas Grobogan dan Anjasmoro (Tabel 5).

Priming air dapat meningkatkan panjang hipokotil dan kecepatan berkecambah sejalan dengan penelitian (Langeroodi \& Noora, 2017) untuk benih kedelai dan jagung (Čanak et al., 2016). Jiang et al. (2020); Lutts et al. (2016) melaporkan hydro priming meningkatkan aktivitas superoksida dismutase (SOD), Catalase (CAT) dan Peroksidase (POX) yang menyebabkan peningkatan perkecambahan benih pada paprika dan gandum.

Tabel 5. Interaksi priming $\mathrm{x}$ varietas pada panjang radikula kecambah pada media dengan cekaman aluminium

\begin{tabular}{lccc}
\hline Priming & Anjasmoro & Burangrang & Grobogan \\
\hline Kontrol & $7,59 \mathrm{~b}$ & $9,65 \mathrm{a}$ & $8,68 \mathrm{ab}$ \\
& $\mathrm{B}$ & $\mathrm{B}$ & $\mathrm{BC}$ \\
Air & $11,61 \mathrm{a}$ & $11,47 \mathrm{a}$ & $10,24 \mathrm{a}$ \\
$\mathrm{KNO}_{3} 1 \%$ & $\mathrm{~A}$ & $\mathrm{AB}$ & $\mathrm{AB}$ \\
& $11,17 \mathrm{a}$ & $11,44 \mathrm{a}$ & $10,39 \mathrm{a}$ \\
$\mathrm{KNO}_{3} 2 \%$ & $\mathrm{~A}$ & $\mathrm{AB}$ & $\mathrm{AB}$ \\
& $10,71 \mathrm{a}$ & $10,56 \mathrm{a}$ & $11,03 \mathrm{a}$ \\
$\mathrm{GA}_{3} 50 \mathrm{ppm}$ & $\mathrm{A}$ & $\mathrm{AB}$ & $\mathrm{A}$ \\
& $11,40 \mathrm{a}$ & $10,77 \mathrm{a}$ & $8,26 \mathrm{~b}$ \\
$\mathrm{GA}_{3} 100 \mathrm{ppm}$ & $\mathrm{A}$ & $\mathrm{A}$ & $\mathrm{C}$ \\
& $9,70 \mathrm{a}$ & $10,34 \mathrm{a}$ & $8,16 \mathrm{~b}$ \\
$\mathrm{PEG} 60007,5 \%$ & $\mathrm{~A}$ & $\mathrm{AB}$ & $\mathrm{C}$ \\
& $7,59 \mathrm{~b}$ & $11,78 \mathrm{a}$ & $8,49 \mathrm{~b}$ \\
\hline
\end{tabular}

Ket : Angka-angka yang diikuti huruf kecil yang sama pada baris yang sama dan angka-angka yang diikuti huruf besar pada kolom yang sama tidak berbeda pada uji BNJ $5 \%$.

\section{SIMPULAN}

Berdasarkan hasil penelitian dapat disimpulkan hal-hal sebagai berikut:

1. Perlakuan priming dengan PEG 6000 $7,5 \%$ merupakan perlakuan terbaik dalam meningkatkan vigor benih kedelai berdasarkan variabel waktu munculnya kecambah dan kecepatan perkecambahan.

2. Benih varietas Burangrang memilki vigor terbaik berdasarkan variabel waktu munculnya kecambah, kecepatan perkecambahan, dan panjang hipokotil. 


\section{DAFTAR PUSTAKA}

Adie, M. M., \& Krisnawati, A. (2016). Identification of soybean genotypes adaptive and productive to acid soil agro-ecosystem. Biodiversitas, 17(2), 565-570.

https://doi.org/10.13057/biodiv/d170 225.

Al-Baldawi, M. H. K., \& Hamza, J. H. (2017). Seed priming effect on field emergence and grain yield in sorghum. Journal of Central European Agriculture, 18(2), 404-423. https://doi.org/10.5513/JCEA01/18.2. 1915.

Amoozadeh, A., Rahmani, S., \& Nemati, F. (2013). Poly(ethylene)glycol/AICl3 as a new and efficient system for multicomponent Biginelli-type synthesis of pyrimidinone derivatives. Heterocyclic Communications, 19(1), 69-73. https://doi.org/10.1515/hc2012-0157.

Anosheh, H. P., Sadeghi, H., \& Emam, Y. (2011). Chemical priming with urea and $\mathrm{KNO}_{3}$ enhances maize hybrids (Zea mays L.) seed viability under abiotic stress. Journal of Crop Science and Biotechnology, 14(4), 289-295. https://doi.org/10.1007/s12892-0110039-x.

Anwar, A., Yu, X., \& Li, Y. (2020). Seed priming as a promising technique to improve growth, chlorophyll, photosynthesis and nutrient contents in cucumber seedlings. Notulae Botanicae Horti Agrobotanici ClujNapoca, 48(1), 116-127. https://doi.org/10.15835/NBHA48111 806.

Badan Statistika Pusat. (2021). Produktivitas Kedelai. BPS. Jakarta. Diunduh 13 Desember 2021.

Badan Statistika Pusat. (2020). Impor Kedelai. BPS. Jakarta.
Balai Penelitian Tanaman Aneka Kacang dan Umbi. (2016). Deskripsi Varietas Unggul Kedelai 1918-2016. Badan litbang. Puslitbangtan. Balitkabi Malang.

Bey, Y., Syafii, W., \& Ngafifah, N. (2005). Pengaruh Pemberian giberelin pada media Vacin dan Went terhadap perkecambahan biji anggrek Bulan (Phalaenopsis amabilis $\mathrm{BI}$ ) secara in vitro. Jurnal Biogenesis, 1(2), 57-61.

Čanak, P., Mirosavljević, M., Ćirić, M., Vujošević, B., Kešelj, J., Stanisavljević, D., \& Mitrović, B. (2016). Seed priming as a method for improving maize seed germination parameters at low temperatures. Ratarstvo i Povrtarstvo, 53(3), 106-110. https://doi.org/10.5937/ratpov5310825

Dewi, R., \& Sutrisno, H. (2013). Pemulihan deteriorasi benih kedelai (Glycine Max L.) dengan aplikasi giberelin. J. Penelitian Pertanian Terapan, 13(2), 116-122.

Janmohammadi, M., Moradi Dezfuli, P., \& Sharifzadeh, F. (2008). Seed Invigoration techniques to improve germination and early growth of inbred line of maize under salinity and drought stress. Gen. Appl. PlAnt PhysioloGy, 34, 3-4.

Jiang, B., Wang, L., Xu, C., \& Yan, M. (2020). Hydropriming enhances the germination of aged ultra-dry wheat seeds. Seed Science and Technology, 48(1),57-63.

https://doi.org/10.15258/sst.2020.48. 1.08 .

Karimi, M., \& Varyani, M. (2016). Role of priming technique in germination parameters of calendula (Calendula officinalis L.) seeds. Journal of Agricultural Sciences, Belgrade, 61(3), 215-226. https://doi.org/10.2298/jas1603215k. 
Kochian, L. V., Hoekenga, O. A., \& Piñeros, M. A. (2004). How do crop plants tolerate acid soils? Mechanisms of aluminum tolerance and phosphorous efficiency. Annual Review of Plant Biology, 55, 459-493. https://doi.org/10.1146/annurev.arpla nt.55.031903.141655.

Kuswantoro, H., Indriani, F. C., Patriawaty, N. R., Sulistyo, A., Han, W. Y., Lee, P. Y., Cho, Y. H., \& Baek, I. Y. (2014). Performance of acid-adaptive soybean expected lines in South Lampung, Indonesia. Agrivita, 36(2), 153-159. https://doi.org/10.17503/Agrivita2014-36-2-p153-159

Langeroodi, A. R. S., \& Noora, R. (2017). Seed priming improves the germination and field performance of soybean under drought stress. Journal of Animal and Plant Sciences, 27(5), 1611-1620.

Latifa, A., \& Diah Rachmawati. (2020). Pengaruh osmopriming benih terhadap pertumbuhan dan morfofisiologi tanaman kangkung darat (Ipomoea reptans Poir) pada cekaman kekeringan. Jurnal Agronomi Indonesia (Indonesian Journal of Agronomy), 48(2), 165-172. https://doi.org/10.24831/jai.v48i2.314 48.

Leite, V. M., Rosolem, C. A., \& Rodrigues, J. D. (2003). Gibberellin and cytokinin effects on soybean growth. Scientia Agricola. 60(3). 537-541. https://doi.org/10.1590/s010390162003000300019.

Lewandowska, S., Łoziński, M., Marczewski, K., Kozak, M., \& Schmidtke, K. (2020). Influence of priming on germination, development, and yield of soybean varieties. Open Agriculture, 5(1), 930935. https://doi.org/10.1515/opag2020-0092.

Lutts, S., Benincasa, P., Wojtyla, L., Kubala, S., Pace, R., Lechowska, K., Quinet, M.,
\& Garnczarska, M. (2016). Seed Priming: New Comprehensive Approaches for an Old Empirical Technique. New Challenges in Seed Biology - Basic and Translational Research Driving Seed Technology, 146. https://doi.org/10.5772/64420.

Marschner, H. (2003). Mineral Nutrition of Higher Plant. Academic Press. Amsterdam.

Maslukah, R., Yulianti, F., Roviq, M., \& Maghfoer, M. D. (2019). Influence of Polyethylene Glycol (PEG) to hardening planlet apple (Malus sp.) by the effect of hyperhydricity on in vitro. PLANTROPICA: Journal of Agricultural Science, $\quad 4(1), \quad 30-38$. https://doi.org/10.21776/ub.jpt.2019. 004.1.4.

Miladinov, Z., Balesevic-Tubic, S., Djordjevic, V., Djukic, V., Ilic, A., \& Cobanovic, L. (2014). Effect of soybean seed priming on germination and vigour depending on the seed lot and sowing date. Ratarstvo i Povrtarstvo, 51(2), 110115.https://doi.org/10.5937/ratpov516572.

Miladinov, Z., Balešević-Tubić, S., Đukić, V., Ilić, A., Čobanović, L., Dozet, G., \& Merkulov-Popadić, L. (2018). Effect of priming on soybean seed germination parameters. Acta Agriculturae Serbica, 23(45),15-26.

https://doi.org/10.5937/aaser1845015 m.

Nawaz, J., Hussain, M., Jabbar, A., Nadeem, G. A., Sajid, M., Subtain, M., \& Shabbir, I. (2013). Seed priming a technique. International Journal of Agriculture and Crop Sciences, 6(20), 1373-1381.

Nugraha, Y. S., Sumarni, T., \& Sulistyono, R. (2014). The influence of interval time and the level provision of water to the growth and yield of soybean (Glycine max ( L ) Merril .). Produksi Tanaman, 2(7), 552-559. 
Pill, W. G., \& Necker, A. D. (2001). The effects of seed treatments on germination and establishment of Kentucky bluegrass (Poa pratensis L.). Seed Science and Technology, 29(1), 65-72.

Singh, D., \& Laxmi, A. (2015). Transcriptional regulation of drought response: A tortuous network of transcriptional factors. Frontiers in Plant Science, 6 (October),1-11.

https://doi.org/10.3389/fpls.2015.008 95.

Sucahyono, D., Sari, M., Surahman, M., Ilyas, S., Raya, J., Payak, K., Malang, K., \& Malang, P. O. B. (2014). Pengaruh Perlakuan invigorasi pada benih kedelai hitam (Glycine soja) terhadap vigor benih, pertumbuhan tanaman, dan hasil. Indonesian Journal of Agronomy, 41(2), 126-132. https://doi.org/10.24831/jai.v41i2.751 7.

Sudrajat, D. (2010). Identifikasi Karakter morfofisiologi kedelai adaptif lahan masam. Jurnal Penelitian Pertanian Terapan, 10(2), 103-110.

Sulaiman, S., Suwignyo, R. A., Hasmeda, M., \& Wijaya, A. (2016). Priming benih padi (Oryza sativa L.) dengan $\mathrm{Zn}$ untuk Meningkatkan vigor bibit pada cekaman terendam. Jurnal Agronomi Indonesia (Indonesian Journal of Agronomy), 44(1), 8. https://doi.org/10.24831/jai.v44i1.124 86.
Supardy, Adelina, E., \& Made, U. (2016). Pengaruh lama perendaman dan konsentrasi Giberelin ( GA3 ) terhadap viabilitas benih kakao (Theobroma cacao L. ). E-J. Agrotekbis, 2(3), 425431.

Timotiwu, P., B. dan Agustiansyah. (2006). Studi perubahan kandungan gula yang dieksudasi tanaman kedelai (Glycine max (L.) Merrill.) pada kondisi stres aluminium. Laporan Hasil Penelitian. Universitas Lampung.

Uguru, M. I., Benedict, Oyiga, C., \& Jandong, E. A. (2012). Responses of some soybean genotypes to different soil $\mathrm{pH}$ regimes in two planting seasons. The African Journal of Plant Science and Biotechnology, 6(1), 26-37.

Ulya, P. D., W. Slamet, \& Karno. (2020). Pertumbuhan dan hasil tanaman cabai keriting (Capsicum annum L.) pada konsentrasi dan lama perendaman giberelin yang berbeda. Jurnal Agro Complex, 4(1), 23-31.

Widyastuti, Y., Purwoko, B. S., \& Yunus, D. M. (2017). Identifikasi Toleransi kekeringan tetua padi hibrida pada fase perkecambahan menggunakan Polietilen Glikol (PEG) 6000. Jurnal Agronomi Indonesia (Indonesian Journal of Agronomy), 44(3), 235. https://doi.org/10.24831/jai.v44i3.137 84 